\title{
The Cooperative Movement and the Education of Working Men and Women: Provision by a Local Society in Lincoln, England, 1861-1914
}

\author{
Andrew J.H. Jackson \\ Bishop Grosseteste University
}

\begin{abstract}
In the second half of the nineteenth century the provision of better education for working-class men and women became one of the various and broad-ranging set of preoccupations of the cooperative movement in Britain. Much early cooperation was economic, concerning alternative means of production and distribution. However, local societies also turned themselves toward other forms of societal improvement, including creating the facilities and contexts that would promote and support the education and learning of adults. The archive of the Lincoln Equitable Co-operative Industrial Society offers a rich body of source material for a microhistorical investigation of the expansion and diversification of one local cooperative up to the First World War. The members' magazine of this local society in particular records the evolution of its purpose-economic, political, social, and cultural. This included achieving progress through various forms of educational provision-although the opportunities for men contrasted with those made available for women. This research illuminates what is a relatively underresearched area - that is, exploration of the complexities, dynamism, and phenomenology of local cooperative adult education and the significance of what it had to offer the development of the labor movement in particular places.
\end{abstract}

\section{Introduction}

The cooperative movement played an important role in the life of local communities in Britain and elsewhere through the later nineteenth century and well into the twentieth. Its origins can be found in the collective desire among the working classes for fair access to unadulterated produce at reasonable prices and through an exchange process in which they could have a democratic stake as members. In the British case much stemmed from the "model" established by the Rochdale "pioneers" in 1844. The ethos of cooperation encompassed the betterment of working families in a broad sense, and extended to the movement's aspirations to secure social, political, and cultural advance for its members, in addition to improving economic conditions.

Local cooperatives were instrumental in implementing the broader cooperation agenda, and, more specifically, making provision for the education of its members. Indeed the cooperative movement, through the work of its local societies, joined with other forms of organizations and associations to promote working-class education up to and following the year 1900. This case study examines in some detail the work of the Lincoln Cooperative and offers a 
microhistory of the development of cooperative education and learning. This local society, now the Lincolnshire Cooperative Ltd., celebrated its 150th anniversary in 2011. To mark this moment, many of its historical records were digitized and published on its website. The members' journal, the Quarterly Record, provides a detailed and compelling account of the establishment and expansion of what began as the Lincoln Equitable Co-operative Industrial Society (LECIS), especially up to $1914 .^{1}$

\section{The Emergence of the Cooperative Movement in the Nineteenth Century}

The origins of the cooperative movement can be found within the gradual evolution of the broader labor movement in modern Britain. ${ }^{2}$ Cooperation was a particular strand of development of existing radical and working-class ideas and politics, with the timing of its rise coinciding with a period of recovery and reassertion following the failure of the Chartist agenda in 1848. From the mid-nineteenth century through to the early twentieth the expansion of cooperation coincided with, among other things, the firmer establishment of trade unionism as well as the gradual achievement of more consolidated working-class political representation through an emerging national Labour Party. Cooperation's formation had a number of reference points. Robert Owen's strand of socialism was one essential ingredient. His early nineteenth-century modeling of local economic, social, and cultural provision through idealized communities was found wanting; and the schemes that he envisaged were larger and more comprehensive than the smaller local enterprises that would comprise the early cooperative societies. Nonetheless, his faith in the self-made, in self-help, and in the possibility of overcoming the circumstances of one's birth left a deep mark on emerging socialist thinking. Chartism, meanwhile, through the 1830 s and 1840 s, had brought into reality mass association. Its "people's charter" for political reform did not succeed. But its representation and mobilization had left an important legacy in popularizing an appreciation of labor power and the force of ideas surrounding societal improvement. Trade unionism had also become established in the first half of the nineteenth century, the legality of trade unions fought for and won with Owen among the leading contributors. In the decades ahead their capacity to challenge modes of economic organization and achieve political representation would be tested.

The growth of cooperation and of the labor movement more widely through the second half of the nineteenth century also owed much to various favorable background conditions, such as economic growth, demographic expansion, rapid urbanization, and industrialization, as well as advances in democratic representation, social infrastructure, leisure provision, print media production, and literacy levels. Cooperation was both one of the outstanding products of this time of change, and, in its part, an agent of change-an instrument of labor activism, and of aspiration and agitation for political, economic, and social progress. ${ }^{3}$ Local cooperative economic practices were not new to the midnineteenth century. However, their substantive, secure, and widespread growth 
is popularly associated in the British context with the Rochdale "Pioneers." The composition of the group's founding membership was significant, a mix of Chartists, Owenites, and trade unionists. The Rochdale Society opted for the principle of distributing its surpluses to its members through a dividend, democratically arrived at. This strategy not only proved essential to the Society's local success, but it also provided a highly influential model of ideal cooperative practice, which would be readily taken up elsewhere. Moreover, Rochdale's blend of economic and social provision, its spirit of utility, thrift, and self-help, proved to be especially attractive to working-class women as well as men. Cooperation in Britain thereafter expanded rapidly, especially in the north of England and in Scotland. By 1871 cooperative societies in England had recruited 250,000 members, and by 1889 membership numbers had reached 850,000.

\section{Working-Class Education in Britain and Cooperation up to 1914}

In the first half of the nineteenth century a number of strands of working-class education had secured a presence. ${ }^{4}$ Early adult schools, which possessed a particular leaning toward religious education and the spread of literacy, were in some evidence - the initiative of churches, chapels, and benevolent societies. Some mechanics' institutes had also appeared, a reflection of a growing interest in industry and science, and, more specifically, a heightening demand for professional, technical, and practical training. In addition, a further strand connected adult education with higher level calls for social reform and political emancipation. This third agenda item can be found among the discourses of Owenism, Chartism, as well as trade unionism in the nineteenth century. In his "Essay on the Formation of Human Character" of 1813, Owen observes that

[a]ny general character, from the best to the worst, from the most ignorant to the most enlightened, may be given to any community, even to the world at large, by the application of proper means; which means are to a great extent at the command and under the control of those who have influence in the affairs of men. ${ }^{5}$

This philosophy - the determination of destiny through educational formation, and the overcoming of the ills of environment and heredity - found representation in the activities of Owenite societies, mutual improvement societies, and working men's associations. These organizations hosted addresses, provided public arenas for debating political issues, and made available contemporary newspapers, periodicals, and other print media.

In the second half of the nineteenth century these early educational developments and underpinning motivations - religious, utilitarian, and politicalcontinued and diversified. ${ }^{6}$ The Quakers were a particular force in furthering the local adult schools more broadly. In some cities a few people's colleges followed in the manner of the mechanics' institutes. Some of the momentum behind the people's colleges and other trades associations was derived from Christian socialism and its crusade against contemporary evils. Much of the 
leadership of these formative institutions comprised those who had benefitted from a university education, and increasingly the universities themselves became involved more directly through extension facilities and classes. The working-class education movement found further impetus through the later nineteenth century. The religious, practical, and political inspirations for offering provision was met by an ever growing demand from an expanding and more expectant working class, a pressing need to address skills shortages, and an inevitable desire to extend the educational reform progress for children to adults. The establishment of the Workers Educational Association (WEA) in 1903 marked something of a coming of age, with this organization providing a developmental framework for bringing together the various interested parties and providers of adult education, including local authorities, universities, cooperatives, trades unions, and political parties.

Into this broadening spectrum of aspirations, intentions, and initiativesphilanthropic, political, religious, utilitarian, professional, and economicstepped the cooperatives. ${ }^{7}$ The influential Rochdale model expressly adopted education among its principles:

INTELLECTUAL IMPROVEMENT OF THE MEMBERS.-That a separate and distinct fund be formed for the intellectual improvement of the members of this Society, and such portion of their families that are in their care, by the maintenance of the library already established and providing such means of instruction as may be considered desirable. The fund for this purpose to be formed by a deduction after the rate of $2 \frac{1}{2}$ per cent per annum on the profits, and the accumulation of all fines levied for infraction of these rules. The management of this fund to be vested in a committee of eleven members appointed for that purpose at the annual meeting and all vacancies to be filled by the quarterly meeting. ${ }^{8}$

This principle was generally taken up and put into practice by emerging cooperative societies elsewhere through the provision of libraries, reading rooms, lectures, and classes. Developments were also given an increasingly strong steer nationally from the 1880 s, with a central education department stimulating the growth of regional and local associations, and the coordination of programs of training and activity. Furthermore, the activities of the women's cooperative guilds became very significant, ranging in their objectives from providing practical instruction to political organization and influence. Moreover, the success of cooperative education meant that it played an influential role in the consolidation of adult education in the first decade of the twentieth century and the establishment of the Worker Education Association. Indeed local cooperatives were instrumental in both the founding of some of the early WEA branch organizations and in the Association's flourishing more broadly. ${ }^{9}$ The formation of the Association, though, did expose some important challenges and areas of tension in this phase in the development of adult education. The university extension movement took a lead position in establishing the WEA, but some contemporary discourse did have cause to question this: 
There is, however, it must be frankly admitted, on the part of leading co-operators, an unpardonable suspicion of the university often flavoured with contempt, and a pronounced antipathy to anything that can possibly be misconstrued into a desire on the part of any movement, educational or otherwise, pushing its own legitimate work, to exploit them. ${ }^{10}$

Cooperative education, in exchanges over legitimacy, could claim to have been endorsed and steered by its working-class membership. The wider narrative of adult education through the nineteenth century and into the early twentieth had instilled enduring ideas and ideals. But it had also comprised failed experiments and weak leadership. Moreover, there was quite often a cultural disconnection evident between those who provided the organization and the working classes they sought to serve. There was also much variance in the degrees to which local cooperatives looked to, placed faith in, and gave way to the developing state infrastructure for providing educational opportunities and services. Notwithstanding, the cooperative movement's experimentation in education was rooted in and defined by its own member body.

The cooperative movement, within the evolution of adult education more broadly up to 1914 , had much to offer particular places. Cooperation's provision was diverse, relatively informal, and general in its character, as much recreational as educational. The First World War highlighted deficiencies in the purpose and standards of national adult education, and the Cooperative movement responded boldly to the challenge. Cooperative education had been seeking to ensure adequate professional and technical programs since the end of the nineteenth century, but it took a far more focused, coordinated, and systematic turn in this direction during the interwar years, especially for society employees. ${ }^{11}$

\section{The Lincolnshire Cooperative 1861-1914}

The development of cooperation in Lincoln can be traced back to 1847 and what was the city's first attempt to establish a local society-the Lincoln and Lincolnshire Flour Mill Society (LLFMS). ${ }^{12}$ However, this enterprise was abandoned after ten years, a consequence of weak management and related financial difficulties. Indeed, the Society's central asset, its mill, which had been built from funds raised through stakeholder subscriptions, had to be sold to discharge what had become unserviceable debts. A second attempt proved more successful, founded upon a combination of social mission and economic prudence. A primary driving force at this point was one Thomas Parker, secretary of the Lincoln Temperance Society. This Society came to host discussions on the benefits of fostering cooperation alongside temperance, in order to secure a greater well-being for working people. Parker obtained insight through teaming up with, among others, one of the former managers of the failed Flour Mill Society, as well as other tradesmen who had been attracted fairly recently to opportunities in what was a developing city. 
A further ingredient was reference to cooperative activity elsewhere and, more specifically, acceptance of the Rochdale "principles." These included one principle that would be at the heart of the economic success and appeal of the cooperative movement more broadly-the remuneration of its members through a dividend paid periodically on the basis of purchases made. This approach was absent from the financial arrangements that had underpinned the Flour Mill Society. The LLFMS was not untypical in this; it was, like other early corn-milling cooperatives, a producer rather than a consumer society, the central endeavour, which was to provide returns on stakeholder capital investments. The adoption and forefronting of the alternative dividend-on-purchases business model was also made possible because the later Society avoided encumbrances relating to investment in real estate in its opening years. Rather than the acquisition of a building plot and the construction of a mill, Lincoln's second cooperative extended itself to no more than a quarterly tenancy of one room of a house, in which it established a store and outlet for a limited range of stock for retail purposes. Indeed the first quarterly report early in 1862 published a creditable, if modest, profit. The cautious philosophy of the second Society is reflected in one of its two mottos, "Slow but sure" (the other being "Union is strength"), which appeared for the first time in an 1863 balance sheet. ${ }^{13}$

The opening reports of the Society are largely columns of debit and credit and stock values. There is some text addressing members, offering an overview of the health of the Society, and occasionally restating the force, breadth, and worth of the movement in stirring terms. A quotation two years into the life of the Society stands out, printed below financial account columns:

Be of one mind in support of the truth; have faith in the lovely principle of Co-operation, and you may cast your mountain of woe into the seas of oblivion. Co-Operation aims at elevating men morally, socially, physically, and politically. This it will do by freeing us from the carking cares of Poverty and Wretchedness, which chain millions to a merely animal existence, and blessing us with the plenty and happiness that come of sympathy, and united action for a good end. Enough has been accomplished in a few years to make the hopeful happy, and encourage the most desponding. MEN OF LINCOLN-CO.OPERATE. ${ }^{14}$

The Society would need to publish further exhortations. Uptake of membership and the level of sales were not as hoped for in the opening years. The Society was right to anticipate healthy growth in Lincoln but found itself having to write to its members in quite emphatic terms in order to promote its development:

[I]t is astonishing how rapidly these institutions are springing up all over the country. Since December, 1862, there have been 104 new Societies registered. Lincoln, with its hundreds of mechanics, ought certainly to occupy a prominent position in Co-Operation, and in order to this desirable end, the Committee hope 
that YOU, AS AN INDIVIDUAL MEMBER, WILL PURCHASE ALL YOU POSSIBLY CAN AT THE STORE, so that the full benefit may be felt. ${ }^{15}$

Local preconditions did appear to be amenable. The city's transition from a relatively conservative provincial center would gather pace through the second half of the nineteenth century, as foundries developed rapidly and a substantial industrial working populace established itself. ${ }^{16}$ The initial takeoff of cooperation was slow in Lincoln, however. The Society soon recognized in particular the limitations and poor location of its store, and its relocation to a larger and more accessible site in 1864 was to the fore of a number of measures required to stimulate more activity from the mid-1860s. ${ }^{17}$ At the end of 1866 the Society could strike a note of confidence to accompany its typical bullishness around the benefits of cooperation. Its twenty-first balance sheet observes that its committee

[is] glad to notice that the principles of Co-operation are daily becoming better understood, and appreciated by the working men of this City. It is very cheering to know that there is a steady growth of business, a weekly increase of Members, and a considerable addition to the Capital. ${ }^{18}$

Subsequently, the Society began to realize more firmly the potential for cooperation in Lincoln. Moving into its second decade, the Society began to establish a more satisfactory trajectory (Table 1). ${ }^{19}$ Indeed, the rate of growth required the building of what would become the Society's third central premises, in Silver Street, which was opened in 1874.

Table One The Progress of the Society

\begin{tabular}{rrrrrr}
\hline Year & Membership & \multicolumn{1}{c}{ Sales } & \multicolumn{1}{c}{ Profit } & Reserves & Dividend paid \\
\hline 1861 & 74 & $£ 365$ & $£ 13$ & $£-$ & $£-$ \\
1870 & 850 & $£ 15,842$ & $£ 1,157$ & $£ 32$ & $£ 994$ \\
1880 & 2,072 & $£ 54,221$ & $£ 4,499$ & $£ 263$ & $£ 3,287$ \\
1890 & 6,123 & $£ 147,557$ & $£ 15,496$ & $£ 3,158$ & $£ 18,272$ \\
1900 & 9,849 & $£ 226,286$ & $£ 24,854$ & $£ 8,096$ & $£ 15,775$ \\
1910 & 12,871 & $£ 344,764$ & $£ 38,001$ & $£ 11,855$ & $£ 24,879$ \\
1920 & 20,320 & $£ 1,101,625$ & $£ 65,240$ & $£ 34,905$ & $£ 24,828$
\end{tabular}

In 1886 the Society started to publish and circulate a journal for its members, the Quarterly Record. Before the emergence of this publication, balance sheets regularly encouraged and even implored local members to purchase the national periodicals, The Co-Operator and the Co-operative News. In 1873, for example, a balance sheet remarks, "Your Committee beg your attention to the 'CO-OPERATIVE NEWS;' it is written and printed by 
Co-operators. It ably advocates our principles, and ought to be studied by all who are looking for better times." 20 By the end of the 1860 s the balance sheets were becoming noticeably longer, as a fuller report of the committee was incorporated alongside lengthier sets of accounts. To reflect this, the quarterly document started to assume the title "Report and Balance Sheet." In addition, the expanding balance sheets began to include articles extracted from national cooperative periodicals and other sources, to lend further gravitas to this local publication. The first of the articles chosen was a very apt one, an extract of a speech by the Liberal MP, Christian socialist, social reformer, and supporter of cooperation, Thomas Hughes. A concluding section is suitably stirring:

He [Thomas Hughes] believed that what God had put upon this country to doputting us, as He had, at the front of commercial nations-was, to apply this principle not only in our family life, and not only in the region so called of morals and religion, but to bring home into our practical business life, and to introduce into all the relations of trade and industry, the great ruling principle of DOING AS WE WOULD BE DONE BY; which was the principle that would elevate the whole human race, and make this world a very much better place to live in than it had ever been hitherto. ${ }^{21}$

The Quarterly Record, from the late 1880s, provided far greater room for the Lincoln Society to publish news of its own work, as well as discussion of the progress of cooperation elsewhere. Indeed, the Record provides a valuable account of the development of this local cooperative organization, set against the wider national and occasionally international context. In 1893, for example, the publication considered socialism and a challenge to the status and worth of cooperation alongside other leading elements of the labor movement. Was cooperation, in truth, merely a route for assisting members of the laboring classes into the capitalist middle class?

Propagandism for socialism ... is made up of two sides, both very active. One is the militant side, operating in the political sphere, and known as the "Labour party." ... The other part of this propagandism for socialism is the intellectual side, composed of the philosophical writers of the Fabian Society ... Co-operation has at present more than a million members the bulk of whom, when they joined it, had no capital at all, and some thousand of them by means of it have been raised in to the "upper working classes." But when they got there they didn't close the door as the joint-stock people have always done. The door to cooperation is as wide open now as ever it was, to enable some more thousands to do the same thing over again. ${ }^{22}$

The balance sheets, and the companion editions of the Record, amply chart the local development of the Society over its first half century. The economic success of Lincoln's cooperative, measured in membership numbers and sales, tended to 
follow the fortunes of its host city and wider region. The health of agriculture was significant, as was the prosperity of Lincoln's manufacturing base, which depended a great deal on servicing the land with machinery. The rate of progress was not without moments of reverse. The Society showed resilience in times of economic challenge. An 1882 report commented upon a preceding four-year period that had comprised "terms of good and bad trade in the town, and one of continued depression in the surrounding agricultural district." Yet, trade receipts, share capital, and membership had all broadly doubled over this same passage of years, and it could be expected that members could now look forward with confidence to a "manhood of the Society worthy of its lusty and vigorous growth." ${ }^{23}$ In conjunction with its firmer economic foothold, the cooperative came to consider alignment with other local labor organizations and even political representation, to press the interests of the Society and its members:

That the time has now come when we, as Co-operators, should be represented at the Council Table, and we pledge ourselves to use every legitimate means to secure the return of any gentlemen who may be nominated in the Co-operative interest ... no party politics were sought to be introduced into this matter of cooperative representation. The requisition had been signed by all men of all shades of politics, teetotallers, and red republicans among others. It was of importance that we should be directly represented, for although we are already represented as individuals, our representatives do not do us justice so far as Co-operation is concerned. ${ }^{24}$

By its fiftieth anniversary in 1911, the Society had built its third (and far larger) central store, twenty-eight other shops in the city and further afield, and could boast 12,781 members. ${ }^{25}$ A Jubilee report noted on progress:

The glorious succession has gone on from the early days of struggle and darkness, until this Jubilee year of light and power and unparalleled prosperity. We have come into an inheritance; others have laboured, we have entered into their labours. The workers of the past builded well, the foundations were made secure, and, to-day the Lincoln Society is looked up to throughout the country and on the Continent as one of the soundest financial concerns to be found anywhere. $^{26}$

\section{The Lincolnshire Cooperative and Education up to the First World War}

It is evident that the Society's economic growth was slow in building momentum, at least through its first decade. It is also noticeable that its education provision was all the more lagged. The embrace of the need to provide for the intellectual improvement of its members was far from immediate. Histories of the Society highlight the fact that close reference to the rulebook of the Rochdale 
Pioneers was a factor in the success of the establishment of the city's second society. However, it singled out for exclusion, conspicuously, the rule that "a separate and distinct fund be formed for the intellectual improvement of the members of this Society." 27 It is not clear why the Society took this decision. Perhaps it was part of its general attempt not to overreach itself as an enterprise and to make a modest and contained start given the earlier failure of the Flour Mill Society. Two years later, though, the 1863 rule book for Lincoln's second Society accepted, if guardedly so, that "a separate and distinct account shall be kept of the allowance (if any) for educational purposes." 28 Early balance sheets and Records do not account for this undertaking. It is possible that the pressing need to boost membership and sales may have underpinned the rationale, with education being one of the more compelling social and cultural benefits of cooperation. Ten quarter-years into its existence, in March 1864, education receives its first mention in a balance sheet, as part of a passage of political and promotional discourse:

This Society has now been in work (without advertising or making any show) for $2 \frac{1}{2}$ years; it has lived through good and evil report, has had a vast amount of opposition, and yet lives, pays its way, and gives very fair dividends to the Members; -still, Working Men don't see its value. How is it? In all other towns, Co-Operation is daily taking firmer ground amongst the working people of England as their leading social institution, because it ensures not only abundant work and fair wages, but education, recreation, and the rights of Englishmen ... It supplies him and his family with pure food and strong clothing; and in its higher developments promises those enjoyments, social and political, that make life desirable, home happy, the people contented, and the nation great and prosperous. ${ }^{29}$

However, the Society was still not forthcoming in making any form of financial allowance, despite, in 1867, remarking upon the benefits of "intellectual improvement":

Feeling convinced that the Co-operative movement is calculated to be of immense advantage in a moral, intellectual, as well as in a social point of view, we confidently recommend it to our fellow working-men; for we are satisfied that the better Co-operation is understood, and the more thoroughly it is sifted, the better it will be appreciated. ${ }^{30}$

At the opening of the new decade the April "Report and Balance Sheet" reproduced a letter from William Howitt to The Co-Operator. Howitt, a prolific writer on history, religion, and politics, gives emphasis to the instrumental role of education in promoting cooperation. Moreover, Howitt, from a Quaker background, discusses an essential philosophical mutuality that can be found existing between cooperation and religion, and its capacity for bringing societal advance and well-being: 
As to Co-operation, that must follow on a sound and universal education, just as light follows the sun. It is impossible for the people to see and understand who they are, - their real nature, their power, their rights, and their duties, - without at once comprehending the mighty and all-reforming principle of Co-operation ... A sound and Christian education will show to every one his neighbour's rights, as well as his own; but it will, by the omnipotent power of Co-operation, wielded by a whole people, divert the fertilising streams of capital from a few channels, and diffuse them over the entire land. ${ }^{31}$

In an 1871 quarterly report education receives another, if passing, reference in an article entitled "Co-operation: Past, Present and Future": "The man who receives a bonus of $5 \mathrm{~s}$ upon his wages, has that extra sum to spend in food, clothing, and education; thus increasing both comfort, employment, and intelligence, and that hope which produces energy, and elevates the people."32 Rhetorical statements on education and cooperation, then, had periodically appeared in Society accounts, but local action, when it came, materialized rather more quietly. A glimpse as to why deeds were slow to follow words is provided in a few lines of the speech by the city's mayor at the Society's fiftieth anniversary: "One of the great features of the Society is the encouragement of thrift." He added, more specifically, "[W]ith regard to the Educational Department. They had rightly let that stand over until they found themselves in a strong financial position."33

In 1873, twelve years on from the Society's foundation, an education committee had been formed. Its activities did not receive a mention in quarterly reports until 1875, however, when a number of short notices appeared alerting readers to committee-membership elections, an amassing of 300 volumes of books, further calls for subscriptions and grants of books and money, and fundraising events. The committee had been established shortly after the decision had been made to build new central premises at Silver Street, which could accommodate a reading room and library. In the spirit of self-help, a characteristic trait of the Society in its early years, it turned to popular and public appeals to raise funds for these facilities. ${ }^{34}$ In 1876 the Committee could report on the opening of the Free News Room and a Library. However, the Committee also recognized at this early stage its limitations in terms of providing for women, as well as the need for dedicated funding by the Society itself:

It is to be regretted that, while the News Room furnishes ample reading for men, the same opportunity for rational education cannot be extended to members' wives, whose domestic duties prevent them from visiting the News Room; because our Library is not large enough to enable us to circulate the books; we commend this to the serious consideration of our brother members, and trust that ere long a small grant may be made quarterly towards augmenting the library.

This first report of the Education Department also indicates the involvement of the church in the early establishment of the library. The bishop, the cathedral chancellor (who would open the facilities on September 30,1876), and two other local clerics 
had delivered, or were due to deliver, addresses at fund-raising events; and a small grant of books had been received by the Society for the Promotion of Christian Knowledge. ${ }^{35}$ The contribution of church leaders and others was acknowledged at the fiftieth anniversary: "By the small upper and intellectual element in the population, the Society has always been held in high regard, and its educational efforts have always received assistance from this class." The author of this half-centenary piece also reflected on what had preceded the Cooperative's provision:

There were no free reading rooms in the city. The frequenters of the Mechanics' Institute, most of whom were not mechanics, but decorous middle-class folk, shrank from the few artisan members who had vitality enough left at night to call in and read for half an hour, unwashed and with clothes unchanged, after working overtime. ${ }^{36}$

In October 1877 the Society would finally implement the one Rochdale rule that had been left outstanding. The committee, with no accompanying comment, reported that $£ 94$ s and $9 \mathrm{~d}$ would be set aside per quarter for "Educational purposes." This was at the rate of one and one-quarter of the net profits, less than the recommendation of Rule 42, but it was a grant nonetheless. The Educational Department Committee did not comment on the grant either but thanked those donating books, including the former chancellor, and now bishop of Truro, and a local MP, and noted that the library was now in a position to service the circulation of its stock. ${ }^{37}$ To give the Lincoln Society some due credit, this step was taken in advance of the campaign to address a general reluctance to embrace an educational mission, driven by the Central Education Department of the Cooperative Union. ${ }^{38}$ Indeed the work of this national department finds scant mention in the Lincoln Quarterly Record.

The report of the following year was able to comment on the success of circulation. Expenditure on new books had reached $£ 12$ 9s over the preceding year, and an account is given of the book-purchasing strategy. Buying focused on those books "most in demand" among the membership - that is, "Standard Works of Fiction, Popular Histories, and Illustrated Books of Travel"-but there was also a wish not "to shut out" requests for "Scientific Works, Books of Reference, and those which treat of specialities." ${ }^{39}$ By the end of 1879 a salaried librarian had been engaged, and the library's collection had been catalogued and a catalogue published, organized by "Fiction, Serials, Travels, Popular Sketches, and Miscellaneous Works, the latter class comprising books of reference, essays, sermons, and poetry." ${ }^{40}$ In its twentieth year the Society's annual report remarked that the work of the Educational Department had "increased in usefulness, and made substantial progress side by side with other departments of the society." The report also indicates how the Department had started to turn its attention more significantly away from the internal concerns surrounding the establishment of the library, and toward outward activity, recorded in "propagandist meetings" and "expenses of delegates to conferences." However, the report also expressed concerns about attendance levels at public readings of papers by speakers, observing, "This is probably owing to the great 
amount of overtime worked at the large firms in the city, and not from any disinclination on the part of members to attend meetings of this kind." 41 In 1882 the library extended its opening hours to respond to the further expansion of the Society into Lincolnshire through new branch stores, branch meetings, and other activities. Sessions on Saturday and Monday evenings were supplemented by an hour on Friday afternoons "at the request of members residing in the country." 42 Through the 1880 s items listed in the accounts of the Educational Committee indicate an increase in the wider social and cultural purpose of its work, beyond servicing the library, including the arranging of trips and concerts, flowers shows, and the award of prizes.

The expansion of the Quarterly Record, and its inclusion of more articles from other media sources, and an invitation for correspondence allowed for topics like education to be discussed more fully and set in a wider scene. The edition of April 1887 is noticeable in this regard. An extract from a conference paper referred to the tension in cooperation between optimizing and reconciling economic and social aims. The author also felt that financial contributions to the Central Board and its broader mission were vulnerable to local selfishness. However, education had a significant role to play:

This is the burning desire to increase the dividend which is so largely encouraged by general committees - some of whom would rejoice if the amount spent in education and given to provident purposes could be appropriated to the same selfish ends ... I suppose, so long as selfishness forms so large a part of human nature, we shall have it asserting itself, more or less, in our midst ... We shall not be doing our duty if we leave the correcting of these influences to the mere chapter of accidents. We must meet them in an organised way. ${ }^{43}$

In a subsequent article a correspondent praises not only the form and function of the new Quarterly Record, but also its connection with the need for the education of members and the role of Lincoln's Education Committee:

You have a free press indeed! In fact, in every sense of the word, you may call it free.-Many a good cause has fallen through for want of a press to advocate its principle-you in your wisdom and strength, have supplied this all important need by publishing a Quarterly Record. All honour to your Educational Committee. It is a tangible proof they possess something more than a name. It may become a splendid telephone between the members and their committee, as a well as a good local co-operative educator. ${ }^{44}$

This edition of the Record, in addition, refers to further debate and developments relating to cooperative education in this period, with an article on the availability of university scholarships, administered by the Co-operative United Board, funded through subscriptions given in testimonial to the work of Mr Thomas Hughes. This is followed by a letter from a Lincoln resident commenting that scholarships "would benefit only a very few, and the most needy 
would be passed by" and that the foundation of friendly-society or cooperativesociety funded schools for cooperators would be possible ways forward: "We are anxious for the privileges of co-operation, and we must be prepared to accept the responsibilities." Moreover, in another letter, "Written expressly for "The Lincoln Co-operative Record," a second author adds:

If, as seems to be the steadily increasing opinion, every child in the Kingdom should have the chance of climbing as high on the intellectual ladder as he is fit to go, without any hindrance from accidental impediments of birth and social position, then that end can be attained only by some scheme of Free Education. ${ }^{45}$

At the close of the 1880s an article in the Record discussed the tensions arising between a Society's committee, its departments, and its members at a time of expansion. By way of self-critique, the article observed that "the current theory is that the Committee reflect the views of the members for whom they act, but the truer conclusion is that in most cases they create rather than passively represent opinion." The committee was challenged with removing "ignorance and avarice and selfishness and if possible to put in their place new and more generous opinions" while ensuring that between the committee and the society "the closest and most amicable relations should exist." Again, education had a part to play. Educational meetings, alongside those concerned with business and social gatherings, had a function to perform in securing efficiency, cohesion and ethos - "for they are the true index of a society's life, and they often develop latent intelligence which, but for them, might have lain dormant forever." This message was reinforced a few years later: "All members of cooperative societies have a voice in management, and on account of this all means at our disposal should be employed to make them acquainted with all the objects, aims, and details in connection with our movement."46

The 1880 s closed with a sense that the educational facilities of the Society had made secure progress. The central buildings along Silver Street and Free School Lane had been extended to provide for more generous accommodation. Society reports had, to date, tended to be quite reticent about this area of provision, but in 1890 there appeared a report that most directly and explicitly celebrated what had been achieved and its significance in the life of the Society in the new buildings:

[F]itly crowning them are the noble rooms devoted to Educational and Social purposes, where the members, conscious that they are in an institution free from the deadening influence of patronage, cannot fail to be quickened in responsibility, independence and self-reliance, healthful feelings, among the many that cooperation so unmistakenly promotes. ${ }^{47}$

By 1890 the quarterly grant had risen to $£ 423$ s and 9d. Library opening hours had been extended to four evenings and one afternoon, and these would be mirrored in the hours of a new refreshments bar for members. The ever expanding 
Record had capacity for more information on the Society's goods and services, including that of the Library and Reading Room. One feature gives an insight into the quantity and quality of the stock that was being provided by this time. On newspapers and periodicals alone, members could consult the following:

DAILY PAPERS. - Standard, Daily News, Daily Chronicle, Daily Telegraph, Pall Mall Gazette, Manchester Guardian, Manchester Examiner, Leeds Mercury, Sheffield Independent, The Star, Nottingham Post, Manchester Evening News and The Daily Graphic

WEEKLY PAPERS.-Lincoln Gazette, Lincolnshire Chronicle, Boston Guardian, Nottinghamshire Guardian, Horncastle News, Spalding Free Press, Newark Advertiser, Isle of Axholme and Gsinsborough News, Sleaford Gazette, Grantham Journal, Exchange and Mart, The Spectator, Stamford Mercury, Cassell's Saturday Journal, Newcastle Chronicle, Leeds Mercury, Public Opinion, and Co-operative News.

ILLUSTRATED PAPERS. - The Graphic, Engineer, Building News, Figaro, The Queen, Punch, Judy, Fun, and the Illustrated London News.

MAGAZINES. - Leisure Hour, Cassell's Family Magazine, Chambers's Journal, Good Words, New Review, Harper's Magazine, Fortnightly Review, The Century, English Illustrated Magazine, Harper's Young People, Nineteenth Century, and All The Year Round. ${ }^{48}$

Demand and supply continued to grow. After two decades the number of daily paper subscriptions had increased from thirteen in 1890 to twenty in 1912, and the illustrated papers from eighteen to thirty-seven. Also, the 300 books that had been acquired in 1875 had become a stock of 5,370 for borrowing, servicing 45,984 issues to members through 1912, and 115 books for reference. A few years earlier, in 1904, is a rare indication of the stock being acquired, with a notice of "Historical, Scientific, Bibliographical, and other Works recently added." It is difficult to discern how representative this list is of the nature of the catalogue in general, but it does give some indication of the interests and ends being served. Of the thirty-three titles, two categories dominate, with eight titles relating to engineering, mechanics, and mathematics, and another eight on horticulture and agriculture. ${ }^{49}$

Through the 1880s and 1890s the burgeoning Quarterly Record also made room for articles outlining continental examples of cooperative provision and the place of education. The first is in 1890. In a discussion of the Familistere of Guise, in France, a foundry cooperative, contrasting impressions are given on how far its industrial, as well as its theatrical, school, and sporting facilities, represented "an ugly utopia," or, in the view of the E.V. Neale, at least, a leading cooperator, a "good shop." 50 No reference, though, is made to Lincoln, and whether its Society ought to make note of what was being modeled. Further, fuller articles appear on the potential of cooperative education. An extract from the West Durham Co-operative Record articulates the 
economic argument that while for "the great majority of co-operators ... all expenditure akin to educational grants is regarded as unnecessary," the Rochdale Pioneers felt that education could be "made to pay":

Every trade is demanding greater intelligence from its workers, with a view to increasing output; and it is the teaching of every economist that, in the production of wealth, man's efficiency is dependent upon his knowledge and mental abilities and moral character, as well as his physical strength. ${ }^{51}$

At the same moment a new subscription appeared in the accounts of the Education Committee, to the "Technical Education Association." It is uncertain whether any form of work-based skills training was being provided under the auspices of the Committee, although in 1891 first-aid courses had begun, to be followed by "Sick Nursing Classes for Women" a year later. In various balance sheets over preceding decades reference had been made to forms of prizes. Their likely content is indicated in an 1892 Record, which lists prizewinners in reciting and singing. ${ }^{52}$ It is evident from reports in the Quarterly Record that the Adult and Junior Society's choirs not only provided a popular social opportunity for the Society's members, but through public performances served a promotional function on behalf of the Cooperative. ${ }^{53}$ The library and reading room remained an important resource. Early reports had commented on their heavy use, which was sustained in part because of the late arrival in Lincoln of a public library. The Society's provision in this library was a reflection of its broader reformist activity in a city where municipal enterprise was slow to develop:

With much satisfaction social reformers recognise of the Society a voluntary body slowly, quietly, and successfully solving some of those intricate problems which opportunist politicians decline to grapple with seriously. By extending its operations to the villages, it has assisted and is assisting the agricultural working class to become producers on their own account. It has been the pioneers in this City of reasonable working hours for shop assistants, and was the first to grant the weekly half-holiday. Our municipal free library, secured at last after being, in turn with the public baths, the football of a generation of town councillors, has to depend upon private munificence for its furnishing of books, the Society's Education Department Rooms have been open free to all since 1870. Comfortable, well appointed, well finished with books and newspapers, paid for and upheld voluntarily by working-class co-operators, they convey a silent but eloquent reproach to those who, while they become connected with corporate and other public bodies solely to obtain advantage for themselves, do not hesitate to accuse our Society of selfishness and to breath prayer for its speedy downfall. ${ }^{54}$

From the early years of the Education Committee its accounts had made reference to congress expenses of its members, and by the 1890 s the more capacious Quarterly Record was able to include reports of the business of the national and 
other cooperative congresses elsewhere. In April 1891 the Record could announce the forthcoming hosting of the national congress in Lincoln. Among the notices members read of the progress of the central Co-operative Women's Guild, and a recommendation that Lincoln consider establishing a branch: "[I]t should not be difficult to get together sufficient ladies connected with our Society ... More than half of the success of many Co-operative Societies is attributable to Women." 55 The congress in the following year was held in Rochdale, and an account is given of that Society's eighteen circulating libraries and a central library and splendidly appointed reading room:

The Society spends yearly $2 \frac{1}{2}$ per cent of its nett profits in education, and the natural result is a general tendency in the working population to create manufacturies and institutions of all kinds in the management and profits of which they can participate. Co-operation has this effect indeed everywhere, but it is specially noticeable in this town where the movement began, and all along has been so successful. ${ }^{56}$

Provision for the education of women took a step forward in Lincoln in 1892 with an announcement of the intent to establish a local guild: "[T]he objects of the Women's Co-operative Guild are to organize women as Co-operators for the study and practice of Co-operation and other methods of social reform, and to attempt to secure improved conditions of domestic life". 57

Such intent is reflected soon afterward in the balance sheets for the following year, with a grant received by the Education Committee for guild work; congress expenses; gym fittings, which would support gymnasium classes for boys and girls; "A Gymnastic Training for Girls" and a "Sick Nursing Class now for women ... alternating with Social Meetings"; and a "course of lectures on domestic economy." 58

The developing provision for women into the early twentieth century can be set in the context of a further widening of the work of the Education Department, with additional activities for adults and children falling within its remit, including bookkeeping classes "for the benefit of our employees," an ambulance class for boys between twelve and sixteen, a nursing class for girls ages sixteen to eighteen, and the availability of sick-room appliances for home use. These joined well-established activities around the gymnasium and choirs. ${ }^{59}$ By its half century the Lincoln Society had formed four Women's Guilds. At the beginning of 1912, of the $£ 13015 \mathrm{~s} 9.5 \mathrm{~d}$ of quarterly expenditure, the two largest areas of outlay were in the purchase of newspapers and magazines ( $£ 125 \mathrm{~s} \mathrm{0d})$ and in the ongoing pursuit of promotion of cooperative principles and expanding greater membership in Lincoln and the wider county, propaganda (£12 4s 3d). Third came grants to the Women’s Guilds ( $£ 119 \mathrm{~s} 0 \mathrm{~d}){ }^{60}$ The program of social meetings listed in reports of two of the branches in that year is typical of the mix of political issues, cooperative propaganda and selfpromotion, practical instruction, and information: 
The Bracebridge Branch of the Womens' Co-operative Guild. Committee Report: ... "Josephine Butler" ... "Our goodly heritage"..."Cookery" ... "Provincialism's dialect accent" ... "Women and their place" ..."Dividends" ... "A Co-operative trip to Switzerland" ... "A Co-operative breakfast table" ... "Co-operation and our duty towards it" ... "The benefit of Co-operation" ... "A visit to Leighton Crockery Works."61

The Burton Road Branch of the Womens' Co-operative Guild. Committee Report: ... "Womanhood" ... "Florence Nightingale"” ... "Josephine Butler" ... "Co-operation" ... "Guildwork" ... "Cookery" ... "Co-operation in the light of the Gospel" ... "What womens' suffrage really means" ... "The guild and its relation to the Society" ... "The Guild Convalescent Fund" ... "Guild work" ... "Co-operative production sample" ... "Dreams and their interpretations" ... "Seventy years of progress" ... "Benefits of co-operation" ... "Co-operation vs trusts." 62

By the second decade of the twentieth century Society lectures, talks, and classes seemed to be reaching women and children more than men. It is difficult to establish what events with speakers were planned with the intention of attracting attendance by male members, for notice of them features far less in the Quarterly Record. The level of provision appears to be considerably lower than the conspicuously expansive and well-documented provision for women through the Guilds. Concerns had been noted in the Educational Department's early years about the low attendance of working men, given employment demands. There are occasional passing notes to open lectures, which men would be encouraged to attend, such as one in 1911 on "Co-operative Small Holdings"; but mention of such events is relatively rare. ${ }^{63}$ Some explanation of this is given in 1914. Well-attended lectures, open to men and women, could be reported in that year on "The Siege of Paris" and "The Stone Age," and the hope was expressed that a few more might be arranged and given by "first class men." It was a "step in the right direction," and there was evidence that the series was finding appeal among "youths eager to get all the good they could out of it, so as to be of some help to them in their future career," as well among "men and women there whose hair had become almost white, and these enjoyed the lectures, and were glad to hear something they could learn." The establishment of a Guild specifically for men would have to await $1920 .^{64}$

On eve of the First World War the work of the Education Department of this one local cooperative society was well established, diverse, and multifaceted. Moreover, as a declaration of support for the wider adult education movement, Lincoln's Co-operative Guild, along with unionists and church leaders, were instrumental in the establishment of the city's branch of the WEA. ${ }^{65}$

\section{Conclusion}

Now that the Society has attained its Jubilee, if it desires to remain strong, to face the future fearlessly, to safeguard the working-classes from exploitation, it must promote that kind of education which will ensure from its members a watchful 
and generous interest in all the progressive forces that the next half-century promises to bring into existence, effectively co-operation by legislation, for the amelioration of the condition of the masses who ask for the blessings of peace and seek to promote the fraternity of mankind. ${ }^{66}$

The discourse to be found within the publications of the Lincolnshire Cooperative was of its age. It could be effusively positive and self-promoting, in the manner of the "boosterist" language employed widely in local newspapers and other print sources of this period. ${ }^{67}$ However, that same discourse was not without self-reflection and self-criticism. The Society regularly reflected deeply and pointedly on its, and more broadly, cooperation's ethos and operations and how well the cooperative movement, local and national, was living up to its ideals and principles. Clearly education played an important part in the narrative and self-justification of cooperation-developing economic endeavor was accompanied, and contained, by the imperative of achieving political and social improvement, including intellectual advance. The Lincoln's Society's account of its developing education provision may be lacking by way of critical self-examination. There is little in the Record to indicate that the Lincoln Society had run especially problematically into some of the typical challenges evident in emerging cooperative and adult education more generally-that is, balancing and reconciling tensions between recreational and more formal activity, practical and theoretical instruction, the provision for men and for women, and cooperative offerings alongside those provided by the local state and the WEA. ${ }^{68}$ Nonetheless, for the historian, it is a rich explanation of the evolution of its education work and how this reflects microhistorically on cooperation's broader task.

The Lincoln example sheds case-specific light on the wider development of cooperative education and sits well alongside other local studies in the emergence of local adult education. ${ }^{69}$ The "plurality of co-operative origins, ideological positions and practical adaptations to specific socio-economic and political contexts" was a conspicuous feature of cooperation's development, locally and globally. ${ }^{70}$ By the close of the nineteenth century, it had become apparent that there were many societies that had not put into practice the hopes for, and ideals of, cooperative education. Furthermore, there were other societies for which what had been created and offered up was being wound down, as expectations mounted regarding education provision by local authorities, the WEA, and university extension. Meanwhile, into the early twentieth century, there was also a reluctance among a further category of societies to hand over to the local state that had been built up. Lincoln can be placed within this grouping. ${ }^{71}$ Its society might have not been quite so prompt in laying on educational facilities and services, but in the context of a reticent municipal and civic culture, it would respond boldly and widely and sustain dedicated investment and maintain services up to and beyond 1914.

Four dimensions emerge from our analysis of the Lincoln Society experience: the interplay between local and general factors and influences; the 
purpose of cooperative education and learning; the substance of what cooperation sought to teach; and the means of its educational engagement.

On the first, microhistory explores the diverse and complex interrelations of causal elements, from the local to the national and beyond, and from the unique to the more generally evident. ${ }^{72}$ The worth of Lincoln's Quarterly Record is in its charting of the formation of the cooperative philosophy of intellectual and educational improvement nationally and how the material and cultural fashioning of that philosophy at the local level was highly subject to the political, economic, and cultural particularities of an individual place and its people. The Lincoln case highlights the degree to which developments were shaped by local factors, rather than being merely passively driven by general forces and central influences. ${ }^{73}$

Second, local cooperative education was aimed internally and externally. Its internal relevance was in educating its members: reminding them of the ethos of the movement and keeping at bay "uncooperative" instincts and tendencies; also enabling them to contribute effectively and appropriately to the efficient and democratic work of the Society. Externally, the educational agenda sought to defend the activities of cooperative societies and to propagandize and, in so doing, attract new members and extend the reach of its services.

Third, like adult education more broadly in this formative period, its content was broadly threefold, incorporating the instilling of higher level philosophical and quasi-religious thinking, as expressed in the founding ideals of cooperation; imparting practical information, and teaching technical and domestic skills; and informing and facilitating political and social reformist action and intervention. In these dimensions the Lincoln Society was in accord with national expectations for the provision of cooperative education, seeking breadth, diversity, and purpose: "primarily, the formation of character and opinions by teaching the history, theory, and principles of the movement ... and, secondarily ... the training of men and women to take part in industrial and social reforms and civic life generally." 74

Finally, education and learning was undertaken and accomplished through a range of means. Society publications were evidently both intellectual and instructive, and Lincoln's Quarterly Record is an outstanding example of this. The library, reading room, and other built facilities offered a great deal in terms of resources and training, as did social gatherings and more formal courses. In addition, the women's guilds very were successful and significant for their role in bringing political ideas and practical instruction to female members of local societies. ${ }^{75}$

\section{NOTES}

1. Andrew Jackson, " 150 Years of History: On Using the Digitised, Open-Access Archive of the Lincolnshire Cooperative," Lincolnshire Past \& Present 89 (2012), 9-10; Alan Middleton, 150 Years of Lincolnshire Co-operative (Lincoln, 2011). The Lincolnshire Cooperative archive was digitized by Bishop Grosseteste University for the Society and is available at http://archive. 
lincolnshire.coop. I am very grateful for the encouragement and support of Alan Middleton during the digitization project and for his reading of and helpful comments on this article. Alan was a director of the Lincolnshire Cooperative for forty-four years and for twenty-five years a member the National Board of Cooperatives UK. The author is also grateful for the comments and pointers provided by the editorial board of this journal and by two anonymous reviewers.

2. G.D.H. Cole, A Short History of the British Working-Class Movement, 1789-1947 (London, 1966), 152-54; Eric Hopkins, Working-Class Self-Help in Nineteenth-Century England (London, 1995), 1-184; E.H. Hunt, British Labour History, 1815-1914 (London, 1981), 189-249; Sidney Pollard, "Nineteenth-Century Co-operation: From Community Building to Shopkeeping," in Essays in Labour History, ed. Asa Briggs and John Saville (London, 1967), 74-90; David Thomson, England in the Nineteenth Century (Harmondsworth, 1987), 46-144; Nigel Todd, "The Wallsend Owenites," Forum 55 (2013): 279-80.

3. Cole, A Short History, 155-61; Hopkins, Working-Class Self-Help, 185-222; Hunt, British Labour History, 250-310; Pollard, "Nineteenth-Century Co-Operation," 90-112; Thomson, England in the Nineteenth Century, 150; Anthony Webster, Linda Shaw, David Stewart, John K. Walton, and Alyson Brown, "The Hidden Alternative," in The Hidden Alternative: Co-Operative Values, Past, Present and Future, ed. Anthony Webster, Linda Shaw, David Stewart, John K. Walton, and Alyson Brown (Manchester, 2011), 5-9.

4. William Devereux, Adult Education in Inner London, 1870-1980 (London, 1982), 1-18; J.F.C. Harrison, Learning and Living, 1790-1960: A Study in the History of the English Adult Education Movement (London, 1961), 3-202; J.W. Hudson, The History of Adult Education (London, 1851); Thomas Kelly, A History of Adult Education in Great Britain from the Middle Ages to the Twentieth Century (Liverpool, 1992), 112-57; Robert Peers, Adult Education: A Comparative Study (London, 1972), 3-30; Todd, "Wallsend Owenites," 280-81; Tom Woodin, "Co-operative Education in Britain during the Nineteenth and Early Twentieth Centuries: Context, Identity and Learning," in Hidden Alternative, ed. Webster (Manchester, 2011), 79-82.

5. In Peers, Adult Education, 23.

6. Devereux, Adult Education, 19-76; Harrison, Learning and Living, 203-72; Kelly, A History of Adult Education, 158-242; Peers, Adult Education, 31-76; W.B Stephens, Adult Education and Society in an Industrial Town: Warrington 1800-1900 (Exeter, 1980); Woodin, "Co-Operative Education," 83-85.

7. Hopkins, Working-Class Self-Help, 213-25; Edmund and Ruth Frow, "The Spark of Independent Working-Class Education: Lancashire, 1909-1930," in The Search for Enlightenment: The Working Class and Adult Education in the Twentieth Century, ed. Brian Simon (Leicester, 1992), 76-77; Harrison, Learning and Living, 105-107, 321-22; Sylvia Harrop, ed., Oxford and Working-Class Education (Nottingham, 1987); Peers, Adult Education, 40-42; Kelly, A History of Adult Education, 243-66; Mary Stocks, The Workers' Educational Association, The First 50 Years (London, 1953), 9-63; Woodin, "Co-Operative Education," 86-88.

8. Unknown, "Rule 42 of the Rochdale's Pioneers' Society," in A Century of Achievement: The Story of Lincoln Co-operative Society, ed. Frank Bruckshaw and Duncan McNab (Lincoln, 1961), 21.

9. Albert Mansbridge, "University Extension Journal, April 1903," in Peers, Adult Education, 63. See also Hopkins, Working-Class Self-Help, 217-25; Kelly, A History of Adult Education, 210, 258-59; Stocks, The Workers' Educational Association, 42; Thomson, England in the Nineteenth Century, 192; Jane L. Thompson, "The Cost and Value of Higher Education to Working-Class Women," in Oxford and Working-Class Education, ed. Harrop, 65; Keith Vernon, "Co-Operative Education and the State, c. 1895-1935," Forum 55 (2013): 2, 293-307; Woodin, "Co-Operative Education," 89-90.

10. Peers, Adult Education, 48-76.

11. Keith Vernon, "Values and Vocation: Educating the Co-operative Workforce, 191839," in Hidden Alternative, ed. Webster, 37-58 (Manchester, 2011).

12. Bruckshaw and McNab, A Century of Achievement, 8; Middleton, 150 Years, 10.

13. Lincoln Equitable Co-operative Industrial Society (LECIS), "Balance Sheet for First Quarter Ending December 17, 1861," January 8, 1862; LECIS, "Balance for Seventh Quarter, Ending June 16th, 1863." See also: Bruckshaw and McNab, A Century of Achievement, 13-24; 
Lincolnshire Co-operative Society Ltd., Serving the Community: Lincoln Co-operative Society Ltd. 1861-1994 (Lincoln, 1994), 3; Middleton, 150 Years, 10-18.

14. LECIS, "Balance Sheet for Seventh Quarter Ending June 16th, 1863," June 29, 1863; Middleton, 150 Years, 19.

15. LECIS, Open Letter from the Committee, July 9, 1864.

16. On the development of Lincoln in this period, see, for example, Andrew J.H. Jackson, "Civic Identity, Municipal Governance and Provincial Newspapers: The Lincoln of Bernard Gilbert, Poet, Critic and Booster, 1914," Urban History 42 (2015): 113-29.

17. LECIS, "Balance Sheet for 13th Quarter, Ending December 13th, 1864." See also Bruckshaw and McNab, A Century of Achievement, 24-48; Lincolnshire Co-operative Society, Serving the Community, 4; Middleton, 150 Years, 18-22.

18. LECIS, "Balance Sheet for 21st Quarter Ending December 18th 1866." This statement also opened the subsequent two balance sheets, ending March 19 and June 18, 1867.

19. Bruckshaw and McNab, A Century of Achievement, 123; Middleton, 150 Years, 175.

20. LECIS, "Report and Balance Sheet for the 47th Quarter, ending July 8th 1873." The Co-Operator was published between 1860 and 1871 , to be replaced in 1871 by the Co-operative News, which is still in existence; Hopkins, Working-Class Self-Help, 209.

21. LECIS, "Report and Balance Sheet for the 33rd Quarter, ending January, 1870." The purchase of twenty-five copies of Thomas Hughes and Edward Neale's A Manual for Co-operators (London, 1881) is drawn to the attention of members in LECIS, "The Report and Balance Sheet for the 81st Quarter, ending January 4th, 1882."

22. The article, "Co-operation and Socialism," is attributed to be "From a Conference Paper by J. Mc Vitie, of Carlisle," Lincoln Co-Operative Quarterly Record (LCQR), New Series. No. 16, October 1893, 9.

23. LECIS, "The Report and Balance Sheet for the 83rd Quarter, Ended July 5th, 1882." See also Bruckshaw and McNab, A Century of Achievement, 28-40; Francis Hill, Victorian Lincoln (Cambridge, 1974), 203; Lincolnshire Co-operative Society, 5; Middleton, 150 Years, 23-36.

24. "Municipal Representation," $L C Q R$, New Series, No. 12, October 1892, 9-10.

25. Bruckshaw and McNab, A Century of Achievement, 41-55; Middleton, 150 Years, 3743.

26. LECIS, “A.D. 1911. Jubilee Year. The Year of Jubilee Has Come,” LCQR, New Series, No. 95, January 1911, 10.

27. Bruckshaw and McNab, A Century of Achievement, 21; Middleton, 150 Years, 100.

28. Bruckshaw and McNab, A Century of Achievement, 98, Middleton, 150 Years, 100.

29. LECIS, "Balance Sheet for Tenth Quarter, Ending March 15th, 1864."

30. LECIS, "Balance Sheet for Twenty-Fifth Quarter Ending December 17th, 1867."

31. LECIS, "Report and Balance Sheet for the 35th Quarter, Ending July 6th, 1870."

32. The piece is otherwise unattributed in terms of its origins; LECIS, "CO-OPERATION: Past, Present and Future.-By Mr. LLOYD JONES.-Concluded," in "Report and Balance Sheet for the 39th Quarter, July 4th, 1871."

33. "Points Made from the Speeches at the Opening of the Exhibition," $L C Q R$, New Series, No. 98, October 1911, 9-10.

34. LECIS, "The Report and Balance Sheet for the 54th Quarter, Ending April 6th, 1875." See also Bruckshaw and McNab, A Century of Achievement, 98-99; Middleton, 150 Years, 1012.

35. LECIS, "The Report and Balance Sheet for the 60th Quarter, Ending October 4th, 1876." See also Bruckshaw and McNab, A Century of Achievement, 98; Middleton, 150 Years, $100-1$.

36. Salis, "Now and Then," LCQR, New Series, No. 97, July 1911, 10. 1877."

37. LECIS, "The Report and Balance Sheet for the 64th Quarter, Ending October 2nd,

38. Vernon, "Values and Vocation," 39.

39. LECIS, "The Report and Balance Sheet for the 68th Quarter, Ending October 8th, 1878."

40. LECIS, "The Report and Balance Sheet for the 71st Quarter, Ending July 7th, 1879." 1882."

41. LECIS, "The Report and Balance Sheet for the 81st Quarter, Ending January 4th, 
42. LECIS, "The Report and Balance Sheet for the 82nd Quarter, Ending April 5th, 1882." See also Maurice Barley, "Postscript," in Twentieth Century Lincolnshire, ed. Dennis R. Mills (Lincoln, 1989), 355; Bruckshaw and McNab, A Century of Achievement, 100; Hill, Victorian Lincoln, 227; Middleton, 150 Years, 102.

43. The article, "Hindrances to the Work of Co-Operative Societies," is attributed as "Extract from a paper read by Mr. J. Thomson at a conference at Aston-under Lyne, January 29, 1887"; LECIS, Quarterly Record (QR), 6, April 1887, 3-5.

44. John Povey (Rochester and District, Co-operative Society, Limited), Letter to the $Q R$, April 1887, 5-6.

45. A. Sharp, "Co-Operative Scholarships," $Q R$, April 1887, 6-7; J. Walker (24, Alexandra Terrace, Lincoln), Letter to the Quarterly Record, April 1887, 7; L.A.T., "Free Education: Written Expressly for The Lincoln Co-operative Record," Quarterly Record, April 1887, 5-6. 46. "The Influence of Committees of Management," $Q R$, April 1889, 1-2; $L C Q R$, New Series, No. 20, October 1894, 9.

47. $L C Q R$, New Series, January 1890,7 ; this is not explicitly dated, but is appended to LECIS, "The Report \& Balance Sheet for the 113th Quarter, Ended January 1st, 1890." See also Bruckshaw and McNab, A Century of Achievement, 100; Middleton, 150 Years, 103.

48. "List of Newspapers and Periodicals Taken in the Reading Room," LCQR, New Series, January 1890, 10. On the expansion of the supply and demand of the press in particular regional newspapers, see, for example, Michael Bromley and Nick Hayes, "Campaigner, Watchdog or Municipal Lackey: Reflections on the Inter-War Provincial Press, Local Identity and Civic Welfarism," Media History 8 (2002): 197-212; Andrew J.H. Jackson, "Provincial Newspapers and the Development of Local Communities: The Creation of a Seaside Resort Newspaper for Ilfracombe, Devon, 1860-1," Family and Community History 13 (2010): 10113; Mary Lester, "Local Newspapers and the Shaping of Local Identity in North-East London c. 1885-1915," International Journal of Regional and Local Studies 13 (2009): 44-62.

49. T. Mathers. "Education Department," LCQR, New Series, 106, October 1913, 6;

"Educational Department," LCQR, New Series, 59, April 1904, 10.

50. $L C Q R$, New Series, July $1890,8$.

51. “Co-Operative Education,” LCQR, New Series, July 1890, 9,

52. LECIS, "The Report \& Balance Sheet for the 115th Quarter, Ended July 2nd, 1890";

“Ambulance Class," LCQR, New Series, No. 6, April 1891, 9; "Notes," LCQR, New Series, No.

9, January 1892, 8; "Prize Winners at the Recent Competitions," $L C Q R$, January 1892, 9.

53. For example, "Educational Department," LCQR, New Series, 67, July 1906, 11.

54. $L C Q R$, New Series, No. 19, July 1894, 8. On local civic culture, reform of social infrastructure and library provision at this time, see Hill, Victorian Lincoln 220-40; Jackson, "Civic Identity," 123-24.

55. LCQR, April 1891, 8. See also Bruckshaw and McNab, A Century of Achievement, 104;

"Lincoln Co-operative Society Ltd. Education Committee," in Co-operative Printing Society Ltd., Women's Guild Co-operative Guild Congress: Lincoln-1942 (Manchester, 1942) 19; Middleton, 150 Years, 111.

56. “Notes," LCQR, New Series, No. 11, July 1892, 9.

57. $L C Q R$, New Series, No. 12, October 1892.

58. LECIS, "The Report and Balance Sheet for the 125th Quarter, Ended January 4th, 1893; 130th quarter, ended April 4th, 1893"; LCQR, January 1893, 8; July 1893, 9.

59. Tom Mathers, "Educational Department," LCQR, New Series, 96, April 1911, 12.

60. LECIS, "The Report and Balance Sheet for the 201st Quarter, Ended January 3rd,

1912." See also “Country Festivals," LCQR, New Series, No. 99, January 1912, 10.

61. LCQR, New Series, No. 101, July 1912, 11.

62. $L C Q R$, July $1912,11-12$.

63. Tom Mathers, "Educational Department," LCQR, New Series, 97, July 1911, 12.

64. Tom Mathers, "Education Department," LCQR, New Series, 108, April 1914, 8; Co-operative Printing Society, Women's Guild Co-operative Guild, 19.

65. LECIS, "The Report and Cash Account, from January 1st to April 1st 1914." See also

Barley, "Postscript," 356.

66. Salis, "Now and Then," LCQR, July 1911, 10-11.

67. Jackson, "Civic identity."

68. Vernon, "Co-Operative Education," 294-301; Woodin, "Co-Operative Education," 84-91. 
69. Devereux, Adult Education, 19-76; Frow and Frow, "The Spark of Independent Working-Class Education," 76-77; Harrison, Learning and Living, 203-72; Hopkins, Working-Class Self-Help, 213-25; Kelly, A History of Adult Education, 158-266; Peers, Adult Education, 31-76; Stephens, Adult Education; Stocks, The Workers' Educational Association, 9-63.

70. Webster et al., "Hidden Alternative," 8.

71. Vernon, "Co-Operative Education," 296-300; "Values and Vocation," 38-39.

72. On microhistory, see, for example, Pat Hudson, "Regional and Local History: Globalisation, Post-Modernism and the Future," Journal of Regional and Local Studies 20 (1999): 5-24; Andrew J.H. Jackson, "Process and Synthesis in the Rethinking of Local History: Perspectives in Essays for a County History Society, 1970-2005," International Journal of Regional and Local Studies 2 (2006): 6-7.

73. Vernon, "Values and Vocation," 55; see also Todd, "Wallsend Owenites."

74. Co-Operative Union Ltd., Co-Operative Educational Programme (Manchester, 1910);

Vernon, "Values and Vocation," 39; see also Woodin, "Co-Operative Education," 90-1.

75. Todd, "Wallsend Owenites," 286; Woodin,"Co-Operative Education," 79-89. 